\title{
Yttrium Y 90 Monoclonal Antibody Hu3S193
}

National Cancer Institute

\section{Source}

National Cancer Institute. Yttrium Y 90 Monoclonal Antibody Hu35193. NCI Thesaurus.

Code C38678.

A radioimmunotherapeutic agent consisting of a humanized murine monoclonal antibody (hu3S193) directed against the tumor-associated Lewis Y epithelial antigen chelated to the radioisotope yttrium-90. Yttrium Y 90 monoclonal antibody Hu3S193 binds to Lewis $Y$ epithelial antigen-expressing tumor cells, selectively delivering a cytotoxic dose of beta radiation. ( $\mathrm{NClO4})$ 